\title{
A Pragmatics Analysis of Deixis in Surah Al Baqarah Translated By Abdullah Yusuf Ali
}

\author{
Irah Khoiriyah Azzahra \\ Institut Agama Islam Negeri (IAIN) Curup \\ irahkhoiriyah@gmail.com
}

\begin{abstract}
This is a descriptive qualitative research that explores about nonperson deixis words in surah Al-Baqarah translated by Abdullah Yusuf Ali, which concern in context reference meaning of pragmatics analysis. The data of this research was taken from 222 verses that consist of non-person deixis. The technique off collecting data is document analysis that uses pragmatics analysis approach. The collected data were checked by an informant. The technique of analyzing data is by managing, reading the script, classifying the data, describing, and interpreting. Then checklist for instrument was built of Levinson's theory. The result of this research presents that 1) there are four types of non-person deixis used in surah Al-Baqarah translated by Abdullah Yusuf Ali namely place deixis, time deixis, social deixis, and discourse deixis. 2) There are 452 references of non-person deixis used in surah Al-Baqarah translated by Abdullah Yusuf Ali (the detail in chapter IV of this research). 3) There are context reference meaning in every deictic word in surah Al-Baqarah translated by Abdullah Yusuf Ali that analyzed. So that the readers should have deep understanding about the representation of pragmatics especially the non-person deixis to analyze the context reference meaning in Al-Qur'an English translation.
\end{abstract}

Keywords: Pragmatics, Deixis, Al-Qur'an English Translation

\section{INTRODUCTION}

According to Levinson, pragmatics study is about the relation between language and context which the relations are relevant to the meaning and the structure of language (Levinson, 1983). There are many words that have different meaning, concept and reference. Some words have clear semantically meaning but no specific meaning pragmatically because the reference is not constant. For examples, some

\author{
ENGLISH FRANCA : Academic Journal of English Language and Education \\ Vol. 3, No. 2, 2019, IAIN Curup \\ P-ISSN 2580-3670, E-ISSN 2580-3689
}


pronouns like that, this, those, these, or temporal terms such as now, yesterday or phrases cannot be defined the reference clearly.

For understanding the meaning pragmatically, Yule divided the coverage of pragmatics into five elements those are presupposition, implicature, entailment, speech act, and deixis (Yule, 1996). Therefore, deixis appears for this kind of problem. They are used to locate actions in a time frame relative to the present. Deixis is a word which its referent always moves depending on the time and space of uttering the word. It is also stated that deixis is a part of pragmatics that has connection with certain word or sentence that changes because of the context. Deixis refers to a word which the referent is unstable and variable, depending on who is the speaker, where and when it is uttered (Khalili, 2017).

The change of context in a sentence is often caused by the change of situation including personal, time and place (Levinson, 1983). The term deixis applies to the use of expressions in which the meaning can be traced directly to features of the act of utterance; when and where it takes place, and who is involved as speaker and as addresser. Levinson states that deixis is the single obvious way in which the relationship between language and context is reflected in the structure of themselves. Deixis cannot be utterly recognized without he added contextual information (Khalil, 2017). Levinson divided deixis theory into five types: person deixis, time deixis, place deixis, discourse deixis, and social deixis (Levinson, 1983).

Occasionally, when reading Al-Qur'an, the readers can find some confusing meaning of the words such as the meaning of word that that could be depended on the situation in the utterance that point to a specific thing. As the explanation before, the readers can understand about the meaning easier if the readers know about the context. It was be found the difficulty of interpreting what is uttering or to what the utterance is uttered, especially in the Al-Qur'an. In this research, researcher choose to analyze the deixis of surah Al-Baqarah because the content of surah Al-Baqarah covers the whole explanation in Al-Quran briefly and the prophet Muhammad (S.A.W) highlighted many of its benefits in general and some of its specific benefits. Yusuf Qardhawi said that Al-quran is a divine book originally as a guide to all muslim and revealed to the Prophet Muhammad. Further, Qardhawi explained that Al-Qur'an is the holy book that contains various teachings, including the 
Iman as a guide to know and trust the essentials of Allah (Qardhawi, 2008).

In addition, some meaning of Al-Qur'an is context dependent that the reference can be only known by seeing the context of utterances. In this research, the writer reveals the translation of Al-Quran which is translated by Abdullah Yusuf Ali as the field of the research. There are some facts that show why Yusuf Ali's work is not doubted by the people. Firstly, Abdullah Yusuf Ali is a famous Al-Qur'an translator who transfers the meaning of Al-Qur'an into English. Secondly, Al-Qur'an is the holy book that each sentence is not needed the right grammatical sentence and no similarities with the other books. Thirdly, Abdullah Yusuf Ali is an intellectual moslem. King Fahd Abdul Aziz stated that Abdullah Yusuf Ali was consequently chosen for its distinguishing characteristics, such a highly elegant style, a choice of words close to the meaning of the original text, accompanied by scholarly notes and commentaries. He is also an Arabic linguist that also master at English. It can be concluded that the product is accurate, acceptable and readable (Ali, 2007). Finally, the reasons about his translation that is not criticized by experts or people are important of the research. Thus, the writer is interested to analyze Abdullah Yusuf Ali's work, especially which is about the nonperson deixis used in Al-Qur'an, in the English translation one.

This research is very important to be done, because Al-Qur'an has a complex meaning that must be learned deeply if someone is interested in learning the context meaning. On the other hand, the writer realizes that to comprehend the meaning in English translation, especially for the people who are not in the field of learning about Al-Qur'an, it is needed a simple way of knowing the meaning of the surah in Al-Qur'an. This research provides the way for the reader to know simply the meaning of surah Al-Baqarah by using pragmatics deixis as the word in pointing via language. Beside that, this is very applicable field, because deixis word can be used in teaching and learning of education. The teacher or lecturer can take examples of deixis from Al-Qur'an.

\section{THEORITICAL FRAMEWORK}

\section{The Notion of Pragmatics}


Pragmatics is the study of the relationship between language and the context, which is a basis in understanding the meaning of language. It is dealing with language use and the relationship between language form and language uses. Kreidler states (Kreidler, 1998) that pragmatics is another branch of linguistics that is concerned with meaning. The focus of pragmatics analysis is on the meaning of words or sentence. In addition, Yule states (Yule, 1996) that pragmatics is the study about the relationship between linguistics form and the use of linguistic term. Further, the theory of deixis is a part of pragmatics and a part of what have been called linguistics performance.

\section{The Notion of Deixis}

Hatch states that the word deixis is derived from the Greek "deicticos" means to show" or to indicates. Deictic (noun of deixis) is used to devote to those elements in language that referred directly to the situation. According to Evelyn Hatch, deictic terms are used to refer to ourselves to others and object in our environment (Hatch, 1995). They are used to locate actions in a time frame relative to the present. Deictic terms show social relationship, the social location and individuals in relation to others. Karl Bühler states that deictic words are words with a reference point that is speaker-or writer-dependent and is determined by the speaker's or writer's position in space and time (Renkema, 2004). Based on the definitions above, the writer concludes that deixis refers to word in which it is referred or its pointing is always moving or changing depends on the speaker, place, and time of utterance. Moreover, the meaning is still relevant with the context.

\section{Kinds of Deixis}

Levinson identified five major types of deictic markers (Cruse, 2000): person deixis, place deixis, time deixis, discourse deixis, and social deixis.

\section{a. Person deixis}

Person deixis is a word that has functions as personal pronoun. Person deixis related with personal pronoun, if its reference which is used appropriate with the context is being used. Person deixis is commonly expressed by pronouns, possessive affixes of nouns, agreement affixes of verb. Person deixis clearly operates on a basic three 
division, exemplified by the pronouns for first person, second person, and third person (Yule, 1996):

1) First person deixis contains of singular pronouns (me, myself, my, mine) and plural pronouns ( $i$, we, us, ourselves, our, ours, am).

2) Second person deixis contains of you, yourself, yourselves, your and yours.

3) Third person deixis contains of He. She, They and suffix $-s$.

\section{b. Place deixis}

a. According to Levinson, place deixis concerns the encoding of spatial locations relative to the location of the participants in the speech. The most importance of locational specification in general can be gauged from the fact that there seem to be two basic ways of referring to object by describing or naming on the one hand, and by locating them on the other. Place deixis can be seen from the use of demonstrative pronouns and also can be seen from demonstrative adverbs of place. It can be proximal (close to the speaker) or distal (away from the speaker). Meanwhile, Givon states that verb 'go' and 'come' is also categorized as place deixis. Verb 'come' as movement close to the location of speaker and verb ' $g o$ ' as movement away to the location of speaker. Based on the definitions above, place deixis can be reflected as the words refer to the location of speech events, and deal with the distance either proximal or distal of speaker's location.

\section{c. Time deixis}

b. According to Levinson, time deixis refers to the time which relative to the time of speaking or an utterance that spoken (Levinson, 1983). It is important to distinguish the moment of utterance (or inscription) or coding time (CD) from the moment of reception or receiving time (RT).

To interpret this expression, the time of the utterance should be known. If it does not happen, the speaker or even hearer will not know if it is a short or a long utterance ahead.

\section{d. Social deixis}

Social deixis is use to code social distinctions that are relative to the participant role in social relationship between speaker and addressee or speaker and some reference (Levinson, 1983). 
While, Fillmore in Levinson states that deixis is concern with the aspect of sentence, reflect, establish or determined by certain realities of the social situation on which the speech act occur (Levinson, 1983). Further, Hatch states that social deixis is code to know social relationship between speaker and addressee or audience (Hatch, 1995). The categories are honorifics, title of address, vocative and pronoun. She also states that there are two tend of social deixis.

1) Absolute deictic are forms uniformly attached to a social role (e.g. "Your Honor" or "Mr. President"). Absolute deictic may involve more than just little title.

2) Relational deictic term after absolute term is to locate person in relation to the speaker rather than their roles in society as a whole. In English, relational deictic may be lexical term (e.g. my husband, cousin, and teacher), pronoun (you and her) or particles.

\section{e. Discourse deixis}

A word can be said as discourse deixis if that word refers to certain part of that text. It is where reference is being made to the current discourse. The words of discourse deixis must contain an explicit performative sentences of gesture or symbolic which draws the attention of the addressee to the referent in the situation of utterance. The use of discourse deixis is also referring to certain text that contains the utterance as a signal and its relation to surrounding text. The implications of discourse in language were described by Fairclough argues that language as a social practice has three implications, namely: (1) discourse cannot be separated from society, (2) discourse is a social process, and (3) discourse processes according to conditioned state in society (Anshori et al, 2019).

Robert de Beaugrande has formulated seven criteria for textuality, that is, criteria that a sequence of sentences must meet in order to qualify as a discourse (Renkema, 2004).

1) Cohesion is the connection that results when the interpretation of a textual element is dependent on another element in the text.

2) Coherence is the connection that is brought about by something outside the text. This "something" is usually knowledge which a listener or reader is assumed to have. 
3) Intentionality means that writers and speakers must have the conscious intention of achieving specific goals with their message, for instance, conveying information or arguing an opinion.

4) Acceptability requires that a sequence of sentences be acceptable to the intended audience in order to qualify as a text.

5) Informativeness is necessary in discourse. A discourse must contain new information. If a reader knows everything contained in a discourse, then it does not qualify.

6) Situationality is essential to textuality. So, it is important to consider the situation in which the discourse has been produced and dealt with.

7) Intertextuality means that a sequence of sentences is related by form or meaning to other sequence of sentences.

In discourse studies most attention has been paid to the first criteria of cohesion and coherence, sometimes taken together as connectivity. Cohesion is usually defined as connectivity that as literally detectable by synonyms and pronominal. Coherence is the connectivity that can be inferred from the discourse by the reader or listener (Renkema, 2004).

\section{Reference}

The philosophical problem of 'referring' brings serious consequences not only for the theory in linguistics, but also for the using of the language because reference is not least a pragmatic problem. The language is used to refer to person and things, directly and indirectly. A correct form of reference is needed to establish who a purpose of reference in the topic is.

According to Bühler, 'unambiguous reference' is what the logics demand of language. In the same spirit, some of the latter in all sincerity proposed that the words should be abolished with 'unclear reference' as 'I' or 'you', because there is no way of checking whether they correspond to something 'out there' as a proper.

Therefore, all pointing expressions have to be related to the uttering person, particular place and at a particular time involves that is linguistic categories as person, place and time. This origin is base line of proper pragmatic meaning in referential context: who is ' $\mathrm{I}$ ' that is speaking, where does 'he' or 'she' speak from, at what point of time? 


\section{Quran English Translation}

Hanafi states that Quran is a set of Allah's commandments which are conveyed by Gabriel to Muhammad as the guideline for people in the universe (Hanafi, 2009). From those definitions, the researcher concludes that Quran is Allah's vision which is received by Muhammad and used for people's ways of life to reach the happiness in the world and the great beyond. In this research, the researcher uses the Quran English translation written by Abdullah Yusuf Ali. Based on Kaplan and Wierzbicka, they accentuate that the encountered phenomena as regards the use of language in both spoken and written discourses are always relatively interwoven (Morganna, 2019).

\section{Surah Al-Baqarah}

Surah Al-Baqarah (البقزة "The Cow") is the longest surah in AlQuran. Surah Al-Baqarah includes a Madani surah and in accordance with the order of its collection and arrangement in the manuscripts included as the second surah. The terms of the order revelation, Surah Al-Baqarah is $87^{\text {th }}$ surah that were taken down and the first surah of the Madani. Surah Al-Baqarah is the largest surah in Al-Qur'an (includes 286 verses) which covers approximately $2 / 5$ overall juz or section in AlQuran and also the longest verse (verse din/tadayun/mudayanah)in which there are 286 verse also included in this surah. The number of words in this surah is 6156 and letters is 26256 . This surah provides the seven crucial things for muslims and covers the whole content of $\mathrm{Al}$ Quran. That is about types of people, Allah's power, warning from Allah to the children of Israil, ka'bah and kiblat for muslim, law in islam, the prophets, and wealth and the law.

Because of the beneficial in this surah, the researcher wanted to analyze the contextual meaning of Al-Quran translation that is really important for muslim to know. In this research, the researcher uses surah Al-Baqarah translated by Abdullah Yusuf Ali as surah that told more about faith, believers, the obligation of muslim, and pray of muslim.

\section{Previous related study}

Review of related research is a review of the previous research that was currently suitable with this research. There are some researchs 
have been done by other researchers before. In this part, the writer used three related researches which had been conducted. First, a research entitled "A Pragmatics Analysis of Deixis Used in English Translation Of Bukhory Hadith" by Emi Wijayanti (Emi, 2011). She classified the types of personal deixis to describe the referent of personal deixis, and to classify the functions of personal deixis that is used in English Translation of Bukhari Hadith. Then, in describing the referent of personal deixis, she employed reported speech theory by Hurford and Brendan.

The second research is entitled "Discourse Analysis of Reference for Allah and Muhammad Word Used in Al-Quran and Hadits English Translation Of Shalat Topics" by Mashita Arianie. She analyzed the reference for Allah and Muhammad word used in Al-Qur'an and Hadits English Translation and the type of references for Allah and Muhammad word that translator uses in Al-Qur'an and Hadits English Translation. Then, the data were analyzed based on the type of reference based on Michael McCharty's theory (Arianie, 2013).

The third research is "Discourse Analysis of the Nikmat Word in the Verse Fabiayyi Aalaa Irabbikumaa Tukadzibaan" of the Chapter in Surah Ar-Rahman" by Nur Hafiza. The problem of her research were what are the words used to represent nikmat word in "Fabiayyi aalaa irabbikumaa tukadzibaan", why does the nikmat word in" Fabiayyi aalaa irabbikumaa tukadzibaan " is represented in different words and what function of "Fabiayyi aalaa irabbikumaa tukadzibaan " sentence used in surah Ar-Rahman. Then, the data were analyzed based on the type of reference based on Siti Annijat Maimunnah's theory (Hafiza, 2015).

By looking into the previous researches, the writer took this research about non-person deixis that contains of place deixis, time deixis, social deixis, and discourse deixis. This research is different from the previous above because the first is this research focused on nonperson deixis from Levinson's theory while the previous research from Yule's theory about person deixis. The second, it can be seen that the object of this research was Al-Quran English Translation from Abdullah Yusuf Ali's work. The last the writer conducted in this research to represent about non-person deixis that never be taken by other researcher.

\section{RESEARCH METHODOLOGY}




\section{Research Design}

The kind of this research is descriptive which is presented in qualitative way and the field of language research is in linguistic field. The writer uses qualitative design because the data collected in the research were description. The writer would analyze the non-person deixis and find the meaning of context related to the sentence.

The term descriptive comes from "to describe". It means describing something like condition, circumstance, situation and activity. Arikunto states (Arikunto, 2010) "Descriptive research purposes to collect information about an indication is real condition tendency when the research done". The writer tried to understand and explore about non person in deixis in surah Al-Baqarah translated by Abdullah Yusuf Ali. This is a descriptive style because the analyzing of data is described verbally. This research is presented in qualitative way. Bogdan and Taylor defined qualitative research is one of research procedures and result descriptive data in the form of words or utterances (Bogdan, 1992).

This research is a deixis analysis. Deixis is a part of pragmatics that has connection with certain word or sentence that changes because of the context. The change of context in sentence is often caused by the change of situation including personal, time and place (Levinson, 1983). This research focused on nonperson deixis that is used in surah AlBaqarah translated by Abdullah Yusuf Ali. Hence, the writer analyzed the place deixis, temporal deixis, social deixis and discourse deixis in surah Al-Baqarah that appears.

\section{Object of the research}

The object of this research is which the source of the data is English translation Al-Qur'an translated by Abdullah Yusuf Ali in surah Al-Baqarah. Surah Al-Baqarah is the largest surah in Al-Qur'an (includes 286 verses) which covers approximately $2 / 5$ overall juz or section in AlQur'an and also the longest verse (verse din / tadayun / mudayanah)in which there are 286 verse also included in this surah. The number of words in this surah is 6156 and letters is 26256 . This surah provides the crucial thing for muslims and covers the whole content of Al Quran. 
Because of the beneficial in this surah, the writer wanted to analyze the contextual meaning of Al-Qur'an translation that is really important for muslim to know. In this research, the writer uses surah AlBaqarah translated by Abdullah Yusuf Ali as surah that told more about faith, believers, the obligation of muslim, and pray of muslim. The writer chose this surah because surah Al-Baqarah is a representative of other surah and the longest surah in Al Quran that contains 286 verses. AlBaqarah consists of many deixis that need to be analyzed. There are 452 non-person deixis words have been found in surah Al-Baqarah. Analyzing this surah will found the meaning of non-person deixis used.

\section{Informant of The Research}

In this research, the writer needs informant in order to get the valid data to check the accuracy of the corpus to make deep comprehension about the pragmatics analysis of deixis in surah AlBaqarah translated by Abdullah Yusuf Ali. To check the accuracy of data from researcher to informant, researcher will use interview. Interview is an important way for a researcher to check the accuracy of data and to verify or refute the impression he or she gained through observation (Jack et al 1932). In this research, the writer used semi-structured interview. Semi-structured interview is free to talk about she or he deems important with little directional influence from the writer (Dowson, 2002). In this research, to do this interview to the informant, he will be given several questions and cross-check the interpretation of deixis analysis in surah Al-Baqarah translated by Abdullah Yusuf Ali and to reinforced the data that was collected by researcher. Besides interview, the writer used field notes.

\section{Technique for Collecting Data}

In this research, researcher is a key instrument. Furthermore, the writer used other technique for collecting the data. There is document analysis. Document analysis is documents that are interpreted by the writer to give voice and meaning around an assessment topic (Jack et al, 1932). The document analysis of this research is Al-Qur'an. It means that non person of deixis in the Quran are the document of this research. The writer collected the data by doing the grand observation on the scripts of the translation of Quran Surah Al-Baqarah by Abdullah Yusuf Ali to find the corpus of data. Grand observation here means the writer read every verse in surah Al-Baqarah in Al-Qur'an, and then read the 
Indonesian by using Mushaf Al-Qur'an and Terjemahannya by Departemen Agama RI and English Translation by Abdullah Yusuf Ali.

In this research, to do this interview to the additional researchers, they would be given several questions and cross-check about the interpretation of deixis in Surah Al-Baqarah translated by Abdullah Yusuf Ali.

\section{Instrument of The Research}

To analyze the use of nonperson deixis and find the reference in surah Al-Baqarah translated by Abdullah Yusuf Ali as Creswell stated that the instrument of choice in naturalistic inquiry is the human (Cresswell, 2007). To support the data, the writer used checklist to find the complete data of deixis use in surah $\mathrm{Al}$ Baqarah translated by Abdullah Yusuf Ali. Checklist is a list of subject, factors, strategies and names which are wanted to search. The purpose was to make systematic note. This instrument allowed the writer to get the valid data in other field because the factors that would be searched have been written in checklist. The writer just wrote check $(\sqrt{ })$ in each subject she wanted to observe.

The writer makes a checklist about deixis from Stephen C. Levinson's theory. The checklist consist the utterance, form of deixis, technique of deixis analysis, the deictic reference, and the reason about deictic reference and sum of the deixis used. The function of raw table is ease to identify of utterance included in place, time, social or discourse deixis by looking the indicators. After the writer completed the raw table, it would get the deictic reference for assuming the contextual meaning of non-person deixis used.

\section{Technique for Analyzing Data}

Data analysis is the process of systematically searching and arranging the interview or other materials that accumulate to increase the understanding of them and enable to present what you have discovered to other (Bogdan, 1982). The analysis of this study is using deixis analysis technique.. After collecting the data, the writer continued to analyze those data. Deixis analysis is used to identify the references of non-person deixis word in Al-Qur'an English translation by Abdullah Yusuf Ali. 
After all process perfectly over, the data of this research was analyzed by using some steps as the following procedures according to Gay (Apriani, 2017); analyzing of the crosscheck result in Arabic language of Al-Qur'an, next continued to crosscheck in English. If it has finished the data will be analyzed based on the type of deixis based on Stephen Levinson's theory. In applying the data, the writer use descriptive qualitative analysis method as follows:

\section{Data Managing}

The writer manages all data to check and make sure the data was complete from Al-Qur'an Translation in surah Al-Baqarah.

\section{Reading the Script}

The writer got all the deixis in surah Al-Baqarah in Al-Qur'an English translation. Then it was continued by reading the script as stated by Hadi that reading is one of skills in English to make readers get information from what they read, and information from a text, it needs a thinking process in order to be able to reach the comprehension (Suhermanto, 2019).

\section{Describing}

After the writer read and classified the phenomenon of the data from English Translation of Al-Qur'an English Translation by Yusuf Ali, the writer described the data that has collected.

\section{Classifying the data}

After the data is gained from the informant about the references of non-person, the writer analyzed the transcription document, read and classify the phenomenon. It would be helping the writer in the research, for example:

a. Facilitate to identify the research problem: The writer is easier to find all the deixis and identify the reference.

b. Help the writer arrange the categorization and sub categorization: After the writer find out all the deixis of the reference in pragmatics analysis that consist of person deixis, place deixis, time deixis, social deixis, and discourse deixis. 
5. Interpreting

The last step is interpreting the writer interpreted about the non-person deixis analysis of reference in Surah Al-Baqarah of AlQur'an English Translation by Yusuf Ali.

\section{FINDINGS AND DISCUSSIONS}

\section{Findings}

\section{Types of Non-Person Deixis found in Surah Al-Baqarah Translated by Abdullah Yusuf Ali}

After collecting the data, the writer found from the 286 verses in surah Al-Baqarah, there are 222 verses consists of deixis and there are 64 verses are none of deixis found. The deixis words consist of the types of non-person deixis in surah Al-Baqarah were classified based on the types of deixis from Levinson. This study finds that place deixis, time deixis, social deixis and discourse deixis occur in surah Al-Baqarah. From the data, the writer found there are 452 non person deixis from 222 verses that found it consists of 121 data $(26,77 \%)$ of place deixis, 91 data $(20,13 \%)$ of time deixis, 129 data $(28,54 \%)$ of social deixis and 111 data $(24,56 \%)$ of discourse deixis. The detail explanation will be presented in the following.

Table 1.

The Frequency of Non-Person Deixis in Surah Al-Baqarah Translated by Abdullah Yusuf Ali

\begin{tabular}{|r|l|c|c|}
\hline \multicolumn{1}{|c|}{ No } & $\begin{array}{c}\text { Type of Non- } \\
\text { Person Deixis }\end{array}$ & Frequency & Percentage \\
\hline 1. & Place Deixis & 121 & $26,77 \%$ \\
\hline 2. & Time Deixis & 91 & $20,13 \%$ \\
\hline 3. & Social Deixis & 129 & $28,54 \%$ \\
\hline 4. & Discourse Deixis & 111 & $24,56 \%$ \\
\hline \multicolumn{2}{r}{ Total } & $\mathbf{4 5 2}$ & $\mathbf{1 0 0 \%}$ \\
\hline
\end{tabular}




\section{a. Place Deixis}

The place deixis is the deixis that concerns the specification of location relative to anchorage points in the utterance. Here the writer shows the finding of place deixis word in Al-Qur'an English Translation of surah Al-Baqarah by Abdullah Yusuf Ali to refer the object by describing or naming and locating via deictic word. There are 121 place deixis found from 451 non person deixis that is analyzed from 221 verses in surah Al-Baqarah that the words are presented in the table. The words below that are included in the table as the place deixis used in surah Al-Baqarah.

Table 2 .

The Finding of Place Deixis in Surah Al-Baqarah Translated by Abdullah Yusuf Ali

\begin{tabular}{|l|l|l|l|}
\hline \multicolumn{1}{|c|}{ Theme of surah } & \multicolumn{1}{|c|}{$\begin{array}{c}\text { Place Deictic Words } \\
\text { Derm }\end{array}$} & $\begin{array}{c}\text { Proximal } \\
\text { Term }\end{array}$ & $\begin{array}{l}\text { Projected } \\
\text { Term or } \\
\text { Specific } \\
\text { Location }\end{array}$ \\
\cline { 2 - 4 } $\begin{array}{l}\text { Types of people for Al- } \\
\text { Qur'an (verse 1-20) }\end{array}$ & - & This, These & - \\
\hline $\begin{array}{l}\text { Allah's Power (verse 21- } \\
\text { 39) }\end{array}$ & There & $\begin{array}{l}\text { This, These, } \\
\text { Here }\end{array}$ & $\begin{array}{l}\text { Come, } \\
\text { Bring }\end{array}$ \\
\hline $\begin{array}{l}\text { Warning from Allah to the } \\
\text { children of Israel (verse } \\
\text { 40-141) }\end{array}$ & There, & This, These & $\begin{array}{l}\text { Bring, } \\
\text { Take, Up, } \\
\text { To, } \\
\text { Above, } \\
\text { Come, } \\
\text { Behind }\end{array}$ \\
\hline $\begin{array}{l}\text { Ka'bah and Kiblat for } \\
\text { Muslim (verse 142-214) }\end{array}$ & That, There & This & $\begin{array}{l}\text { Bring, } \\
\text { Take, } \\
\text { Where, } \\
\text { Come }\end{array}$ \\
\hline $\begin{array}{l}\text { The Prophets and } \\
\text { Lllah's Power (verse 253- }\end{array}$ & se, There & & $\begin{array}{l}\text { Take, } \\
\text { Behind, } \\
\text { Come }\end{array}$ \\
\hline $\begin{array}{l}\text { Law in Islam (verse 215- } \\
\text { 252) }\end{array}$ & That & This, These & $\begin{array}{l}\text { Above, } \\
\text { Behind, }\end{array}$ \\
\hline
\end{tabular}




\begin{tabular}{|l|l|c|l|}
\hline 260) & & & $\begin{array}{l}\text { Bring, } \\
\text { Take }\end{array}$ \\
\hline $\begin{array}{l}\text { Wealth and the law (verse } \\
\text { 261-286) }\end{array}$ & That & - & Take \\
\hline
\end{tabular}

\section{b. Time Deixis}

According to Levinson, time deixis refers to the time which related to the time of speaking or an utterance spoken. The writer found there are 91 time deixis from 451 non person deixis in 221 verses from surah Al-Baqarah. The finding of time deixis word in Al-Qur'an English Translation of surah Al-Baqarah by Abdullah Yusuf Ali is presented in the table below. The time deixis consists of the words that are showed in the table below.

\section{Table 3.}

The Finding of Time Deixis in Surah Al-Baqarah Translated by Abdullah Yusuf Ali

\begin{tabular}{|l|l|}
\hline \multicolumn{1}{|c|}{ Theme of surah } & \multicolumn{1}{|c|}{ Time Deictic Words } \\
\hline $\begin{array}{l}\text { Types of people for Al-Qur'an } \\
\text { (verse 1-20) }\end{array}$ & Before, The Last Day, Every time \\
\hline Allah's Power (verse 21-39) & $\begin{array}{l}\text { Before, Then, Time to time, Every } \\
\text { time, After }\end{array}$ \\
\hline $\begin{array}{l}\text { Warning from Allah to the } \\
\text { children of Israel (verse 40-141) }\end{array}$ & $\begin{array}{l}\text { A Day, Nights, Then, After, Last } \\
\text { Day, Now, A Thousand Years, } \\
\text { Every time, The Day of Judgement, } \\
\text { Before, Soon, The Day }\end{array}$ \\
\hline $\begin{array}{l}\text { Ka'bah and Kiblat for Muslim } \\
\text { (verse 142-214) }\end{array}$ & $\begin{array}{l}\text { Then, After, The Day, The Last Day, } \\
\text { Before, Later, The Night, Dawn }\end{array}$ \\
\hline $\begin{array}{l}\text { Law in Islam (verse 215-252) } \\
\text { The Last Day, Last Day, After, } \\
\text { Before }\end{array}$ \\
\hline $\begin{array}{l}\text { The Prophets and Allah's Power } \\
\text { (verse 253-260) }\end{array}$ & The Day, Before, After, Then \\
\hline $\begin{array}{l}\text { Wealth and the law (verse 261- } \\
\text { 286) }\end{array}$ & Last Day, The Day, Then, Before \\
\hline
\end{tabular}




\section{c. Social Deixis}

Social deixis is used to code the social distinctions that are relative to the participant and concerns with the aspects of sentence, reflect, establish or determined by certain realities of the social situation on which the utterance occurs. The writer presents the data of social deixis that is used in Al-Qur'an English Translation of surah Al-Baqarah by Abdullah Yusuf Ali in the table. The writer found there are 129 social deixis from 452 non person deixis in 222 verses in surah Al-Baqarah that consists of the deictic words below.

Table 4

The Finding of Social Deixis in Surah Al-Baqarah Translated by Abdullah Yusuf Ali

\begin{tabular}{|l|l|}
\hline \multicolumn{1}{|c|}{ Theme of surah } & \multicolumn{1}{|c|}{ Social Deictic Words } \\
\hline $\begin{array}{l}\text { Types of people for Al- } \\
\text { Qur'an (verse 1-20) }\end{array}$ & Lord \\
\hline Allah's Power (verse 21-39) & $\begin{array}{l}\text { Guardian-Lord, Lord, Oft-Returning, } \\
\text { Most Merciful }\end{array}$ \\
\hline $\begin{array}{l}\text { Warning from Allah to the } \\
\text { children of Israel (verse 40- } \\
\text { 141) }\end{array}$ & $\begin{array}{l}\text { Lord, Your Maker, Oft-Returning, Most } \\
\text { Merciful, All Pervading, All Knowing, } \\
\text { Glory, My Lord, The All Hearing, The } \\
\text { All Knowing }\end{array}$ \\
\hline $\begin{array}{l}\text { Ka'bah and Kiblat for Muslim } \\
\text { (verse 142-214) }\end{array}$ & $\begin{array}{l}\text { Lord, Recogniseth, Knoweth, Oft- } \\
\text { Returning, Most Merciful, Most } \\
\text { Gracious, Oft-Forgiving }\end{array}$ \\
\hline $\begin{array}{l}\text { Law in Islam (verse 215- } \\
\text { 252) }\end{array}$ & $\begin{array}{l}\text { Knoweth It Well, Knoweth, Oft- } \\
\text { Forgiving, Most Merciful, One Who } \\
\text { Heareth, Knoweth All Things, Most } \\
\text { Forbearing, Heareth, Exalted in Power, } \\
\text { Wise, Knows, Sees Well, Well } \\
\text { Acquainted, Full Knowledge, Careth, } \\
\text { Lord }\end{array}$ \\
\hline $\begin{array}{l}\text { The Prophets and Allah's } \\
\text { Power (verse 253-260) }\end{array}$ & $\begin{array}{l}\text { The Living, The Self-Subsisting, } \\
\text { Eternal, Most High, The Supreme, } \\
\text { Heareth, Knoweth, Lord, Mighty, Wise }\end{array}$ \\
\hline $\begin{array}{l}\text { Wealth and the law (verse } \\
\text { 261-286) }\end{array}$ & $\begin{array}{l}\text { Careth, Knoweth, Lord, Free All Wants, } \\
\text { Most Forbearing, Seeth Well, Worthy } \\
\text { of All Praise, Careth for All, Knoweth }\end{array}$ \\
\hline
\end{tabular}


All Things, Well Acquainted, Knoweth It Well, Hath Power Over All Things

\section{d. Discourse Deixis}

A word can be said as discourse deixis if that word refers to certain part of the text. The writer found there are 111 discourse deixis from 451 non person deixis in 221 verses of surah Al-Baqarah translated by Abdullah Yusuf Ali. The finding data of discourse deixis word in Al-Qur'an English Translation of surah Al-Baqarah by Abdullah Yusuf Ali are presented in the table above.

Table 5.

The Finding of Discourse Deixis in Surah Al-Baqarah Translated by Abdullah Yusuf Ali

\begin{tabular}{|l|l|}
\hline \multicolumn{1}{|c|}{ Theme of surah } & \multicolumn{1}{c|}{ Discourse Deictic Words } \\
\hline $\begin{array}{l}\text { Types of people for Al-Qur'an } \\
\text { (verse 1-20) }\end{array}$ & Those, These, That \\
\hline Allah's Power (verse 21-39) & Those \\
\hline $\begin{array}{l}\text { Warning from Allah to the } \\
\text { children of Israel (verse 40-141) }\end{array}$ & Those, That, This \\
\hline $\begin{array}{l}\text { Ka'bah and Kiblat for Muslim } \\
\text { (verse 142-214) }\end{array}$ & Those, That \\
\hline Law in Islam (verse 215-252) & Those, That \\
\hline $\begin{array}{l}\text { The Prophets and Allah's Power } \\
\text { (verse 253-260) }\end{array}$ & Those \\
\hline $\begin{array}{l}\text { Wealth and the law (verse 261- } \\
\text { 286) }\end{array}$ & Those, That \\
\hline
\end{tabular}

Reference Meanings of Non-Person Deixis Found in Surah AlBaqarah Translated By Abdullah Yusuf Ali

The writer found that some kinds of deictic words found in surah Al-Baqarah translated by Abdullah Yusuf Ali is consists of the words that has some general meaning in every verse. Some verses that talk about the topic will refer to the same reference meaning. But, if the topic is different, mostly the reference meaning is depended on the utterance in the verse. Here are the general meaning of deictic words in surah AlBaqarah translated by Abdullah Yusuf Ali. 
Table 6.

The General Meaning of The Reference of Non-Person Deixis in Surah Al-Baqarah Translated by Abdullah Yusuf Ali

\begin{tabular}{|c|c|c|c|c|c|}
\hline \multirow{2}{*}{$\begin{array}{l}\text { The } \\
\text { Deictic } \\
\text { Word }\end{array}$} & \multicolumn{4}{|c|}{ Type of non-person deixis } & \multirow[b]{2}{*}{$\begin{array}{l}\text { General } \\
\text { Meaning }\end{array}$} \\
\hline & $\begin{array}{l}\text { Place } \\
\text { Deixis }\end{array}$ & $\begin{array}{l}\text { Time } \\
\text { Deixis }\end{array}$ & $\begin{array}{l}\text { Social } \\
\text { Deixis }\end{array}$ & $\begin{array}{l}\text { Discours } \\
\text { e Deixis }\end{array}$ & \\
\hline That & $\checkmark$ & & & $\checkmark$ & $\begin{array}{l}\text { The meaning of } \\
\text { that in the surah } \\
\text { mostly refers to } \\
\text { the people } \\
\text { - The meaning of } \\
\text { that could be } \\
\text { depended on } \\
\text { the situation in } \\
\text { the utterance } \\
\text { that point to a } \\
\text { specific thing }\end{array}$ \\
\hline This & $\sqrt{ }$ & & & - & $\begin{array}{l}\text { This mostly means } \\
\text { the singular thing } \\
\text { that is pointed in } \\
\text { the utterance that } \\
\text { the thing is kind of } \\
\text { proximal term or } \\
\text { close from the } \\
\text { speaker }\end{array}$ \\
\hline These & $\checkmark$ & & & - & $\begin{array}{l}\text { This mostly means } \\
\text { the plural things } \\
\text { that pointed in the } \\
\text { utterance that the } \\
\text { things are kind of } \\
\text { proximal term or } \\
\text { close from the } \\
\text { speaker }\end{array}$ \\
\hline Those & & & & $\checkmark$ & $\begin{array}{l}\text { The meaning of } \\
\text { that in the surah } \\
\text { mostly refers to the } \\
\text { people }\end{array}$ \\
\hline
\end{tabular}




\begin{tabular}{|c|c|c|c|c|c|}
\hline Here & $\checkmark$ & & & - & $\begin{array}{l}\text { The meaning of } \\
\text { here mostly point } \\
\text { to the specific close } \\
\text { place depend on } \\
\text { the utterance }\end{array}$ \\
\hline There & $\checkmark$ & & & - & $\begin{array}{l}\text { The } \\
\text { meaning of here } \\
\text { mostly point to the } \\
\text { specific far place } \\
\text { depend on the } \\
\text { utterance }\end{array}$ \\
\hline $\begin{array}{l}\text { Come/G } \\
\text { o/Bring/ } \\
\text { Take/Be } \\
\text { hind/Up } \\
\text { /Above }\end{array}$ & $\checkmark$ & & & - & $\begin{array}{l}\text { The meaning of } \\
\text { these deictic words } \\
\text { are depended on } \\
\text { the utterance in the } \\
\text { verse }\end{array}$ \\
\hline Before & & $\checkmark$ & & - & $\begin{array}{l}\text { Before mostly } \\
\text { means all of the } \\
\text { past that has been } \\
\text { happened that } \\
\text { Allah knows even } \\
\text { the people did not } \\
\text { know }\end{array}$ \\
\hline After & & $\checkmark$ & & - & $\begin{array}{l}\text { After mostly the } \\
\text { future that will } \\
\text { happen that Allah } \\
\text { knows, and the } \\
\text { people did not }\end{array}$ \\
\hline Then & & $\checkmark$ & & - & $\begin{array}{l}\text { Then mostly means } \\
\text { the time what will } \\
\text { happen next if the } \\
\text { people } \\
\text { something }\end{array}$ \\
\hline $\begin{array}{l}\text { The Last } \\
\text { Day }\end{array}$ & & $\checkmark$ & & - & $\begin{array}{l}\text { The last day means } \\
\text { the judgement day } \\
\text { when the earth has } \\
\text { been broken }\end{array}$ \\
\hline Lord & & & $\checkmark$ & - & Lord means Allah \\
\hline Now & & $\checkmark$ & & - & $\begin{array}{l}\text { Now mostly means } \\
\text { the current time of } \\
\text { the utterance that }\end{array}$ \\
\hline
\end{tabular}




\begin{tabular}{|l|c|c|c|c|l|}
\hline & & & & $\begin{array}{l}\text { depends on the } \\
\text { situation in the } \\
\text { verse }\end{array}$ \\
\hline Later & - & $\checkmark$ & - & - & $\begin{array}{l}\text { Later mostly means } \\
\text { the time that will } \\
\text { come }\end{array}$ \\
\hline Soon & - & $\checkmark$ & - & - & $\begin{array}{l}\text { Soon means the } \\
\text { time that will come }\end{array}$ \\
\hline
\end{tabular}

\section{Discussions}

The data that have been analyzed by the writer are processed and presented on the table in the findings. In this part, the writer provides the description of reference meaning of non-person deixis in surah Al-Baqarah that talk about faith, believers, the obligation of muslim, and pray of muslim. The discussion contains of the translation of Al-Baqarah that is translated by Abdullah Yusuf Ali below to answer the research question.

\section{Types of Non-Person Deixis in Surah Al-Baqarah Translated By Abdullah Yusuf Ali}

\section{a. Place deixis}

Place deixis or spatial deixis word indicates location in space relative to the speaker. From the seven themes in surah Al-Baqarah translated by Abdullah Yusuf Ali, the writer found and classified the place deixis in the table in finding. It can be seen from the table above that there are three terms of place deixis occur in this surah those are distal term, proximal term, and projected term or specific location.

\section{b. Time deixis}

Time deixis indicates the timing of an event relative to the time of speaking (Cruse, 2006: 179; 2006: 321). From seven theme of this surah, the writer found and classified the time deixis. From the table in finding, it can be seen that time deixis occurs in this Quran translation.

\section{c. Social deixis}


Social deixis is to indicate the position of the referent on the scales of social status and intimacy relative to the speaker (Cruse, 2006: 166). Based on the explanation, the writer concludes that social deixis is mostly used in surah Al-Baqarah Translated by Abdullah Yusuf Ali. The use of social deixis indicates social status and intimacy relative to the people in the relation to Allah.

\section{d. Discourse deixis}

Discourse deixis refers to such matters as the use of "This" pointing of future discourse elements. The use of discourse deixis is also referring to certain text that contains the utterance as a signal and its relation to surrounding text. From the table in finding, it can be found that all the theme in surah Al-Baqarah translated by Abdullah Yusuf Ali use discourse deixis.

\section{Reference Meanings of Non-Person Deixis in Surah Al-Baqarah Translated By Abdullah Yusuf Ali}

In this part, the writer shows the reference meaning of deixis types that are used in every theme in surah Al-Baqarah translated by Abdullah Yusuf Ali. The core purpose of this part is to answer the second question which has been presented in chapter I. Related to the problem statement of this research the writer consults the theory from Levinson. According to Levinson, there are five kinds of deixis and four of five deixis are non-person deixis those are place deixis, time deixis, social deixis, and discourse deixis. The writer also found this kind of nonperson deixis in surah Al-Baqarah translated by Abdullah Yusuf Ali.

\section{Conclusion}

There are four types of non-person deixis analyzed in surah AlBaqarah translated by Abdullah Yusuf Ali those are Place Deixis, Time Deixis, Social Deixis, and Discourse Deixis. Firstly the writer found the frequency of non-person deixis in this translation that there are 452 data of non-person deixis found in surah Al-Baqarah translated by Adullah Yusuf Ali which contain deixis based on Levinson's category. From the data, the writer found 121 data $(26,77 \%)$ of place deixis, 91 data $(20,13 \%)$ of time deixis, 129 data $(28,54 \%)$ of social deixis and 111 data $(24,56 \%)$ of discourse deixis of discourse deixis. Secondly, the writer found that some data has the same reference such as Lord that 
always be referred to Allah, and the others have different reference such as Those mostly referred to the people but in the different setting and different meaning. The writer concluded that the deixis is useful to describe the function of place, time, demonstrative, lexical feature which is connecting the utterance with relation of space and time.

By using this research, the next researcher can understand about the interpretation of deixis. For instance, the next researcher can focus examining one of deixis types by using different object. It is also challenging if the next researcher can connect the theory of deixis with the other studies. Additionally, the writer suggests for being carefully on the references of the deixis used in the Al-Qur'an translation. By using this research, the next researcher can understand about the interpretation of deixis. Besides the deixis, the next researchers can also conduct the same surah but different field such as speech act or another field.

\section{REFERENCES}

Ali, A.Y. (2007). The meaning of the Nobel Quran (Koran).

Anshori, S., \& Sumarlam, S. (2018, November). Critical Discourse Analysis of Online Media News about The Potential of Conflict of Presidential Election 2019. In International Seminar on Recent Language, Literature, and Local Cultural Studies (BASA 2018). Atlantis Press.

Apriani, E. (2017). Utilizing Preservice English Teachers Strategies and Classroom Management at Junior High School in Rejang Lebong Regency. ENGLISH FRANCA: Academic Journal of English Language and Education, 1(2), 149-194.

Arianie, M. (2013). "Discourse Analysis of Reference for Allah and Muhammad Word Used in Al-Quran and Hadits English Translation of Shalat Topics". Skripsi. Fak. Tarbiyah STAIN Curup. Curup.

Arikunto, S. (2010). Prosedur penelitian suatu pendekatan praktek. Jakarta: Rhineka Cipta. 
Bogdan, R.C. (1982). Qualitative Research For Education ;An Interaction To Theory And Method. Toronto: Toronto.

Cresswell. (2007). Qualitative Inquiry and Research Design Choosing among Five Approach, $2^{\text {nd }}$ edition. California: Sage Publication.

Cruse, A. (2000). Meaning in Language. New York: Oxford University Press.

Downing, A. (2002). English Grammar. USA: Routledge.

Dowson, C. (2002). Practical Research Method. Creswell: Wiltshire.

Fromklin, V, Rodman, et.al. (1990). An Introduction to Language. London: Holt Rinehart and Winston.

Gay, L. Rumbel. (2001). Educational research: Competencies for analysis and application (8th ed.). New York: Prentice Hall.

Hafiza, N. (2015) "Discourse Analysis of the Nikmat Word in the verse "Fabiayyi aalaa irabbikumaa tukadzibaan" of the Chapter in Surah Ar-Rahman". Skripsi. Fak. Tarbiyah STAIN Curup. Curup.

Hanafi. (2009) Intisari Pengetahuan Agama Islam Lengkap. Jakarta: Bintang Indonesia.

Hatch, E. (1995). Vocabulary, Semantics and Language Educations. Cambridge University Press.

Hurford \& Brendan. (1994). Semantics: A Course Book. New York: Cambridge University Press.

Khalili, E. (2017). Deixis Analysis in A Tale of Two Cities Written by Charles Dickens. International Academic Journal of Social Sciences, 4 (03), 58-65.

Kreidler. (1998). Introducing to English Semantic. London: Routledge.

Levinson, S. (1983). Pragmatics. New York: Cambridge University Press.

Lyon, J. (1981). Language and Linguistics. Cambridge: University Press. 
Morgana, R. (2019). Indonesian EFL Teacher's Ideologies of Lingua Culture. ENGLISH FRANCA: Academic Journal of English Language and Education, 3(01), 15-40.

Narbuko, C, et.al. (2007). Metodologi Penelitian. Jakarta: PT Bumi Aksara.

Qardhawi, Y. (2008). Bagaimana Berinteraksi Dengan al-Qur'an. Jakarta Timur: Pustaka Kautsar.

R.F, Jack \& E.Wallen, N. (1932). How to Design and Evaluate Research in Education. New York: Mc Graw-Hill.

Renkema, J. (2004). Introduction to Discourse Studies. USA: John Benjamins Publishing Company.

Suhermanto, H. (2019). The Effect of Fix Up Strategy in Enhancing Students' Reading Comprehension in IAIN Curup. ENGLISH FRANCA: Academic Journal of English Language and Education, 3 (01), 1-14.

Wijayanti, E. (2011). "A Pragmatics Analysis of Deixis Used In English Translation of Bukhory Hadith". Skripsi. Fak. Tarbiyah STAIN Curup. Curup.

Yule, G. (1996). Pragmatics. New York: Oxford University Press. 
222 | ENGLISH FRANCA, Vol. 3, No. 2, 2019 